\title{
Sailing Together or Ships Passing in the Night? India and the United States in Southeast Asia
}

Walter C. Ladwig III and Anit Mukherjee

Asia Policy, Volume 14, No 1 (January 2019)

WALTER C. LADWIG III is an Associate Professor of International Relations in the Department of War Studies at King's College London. He is the author of The Forgotten Front: Patron-Client Relationships in Counterinsurgency (2017). He can be reached at<walter.ladwig@kcl.ac.uk>.

ANIT MUKHERJEE is an Assistant Professor at the S. Rajaratnam School of International Studies at Nanyang Technological University in Singapore. He can be reached at<isamukherjee@ntu.edu.sg>.

NOTE: The authors would like to thank Cara Abercrombie, Rajesh Basrur, Joshua White, and the participants at the January 2018 workshop "A Global Partnership or a Relationship Oversold? Taking Stock of the India-U.S. Strategic Relationship," organized by the S. Rajaratnam School of International Studies, for their feedback and comments on this paper. 


\section{EXECUTIVE SUMMARY}

The United States' and India's policies toward Southeast Asia are characterized by a significant congruence of interests. This article assesses both the prospects and constraints New Delhi and Washington face in coordinating their policies toward the region.

\section{Main Argument}

Political leaders and analysts have described U.S.-India relations as a global partnership with the potential to shape the future security architecture of the Indo-Pacific. As is widely acknowledged, the two countries' extraregional interests align most closely in Southeast Asia. Accordingly, this article examines the potential for and limitations of U.S. and Indian cooperation in the region to achieve shared aims. It argues that extensive diplomatic consultations between the two countries have led to a significant convergence in their positions on regional security challenges. Active cooperation, however, remains constrained by a number of factors, including India's need to prioritize foreign policy challenges closer to home, concerns about provoking China, and a discomfort among countries in Southeast Asia regarding the idea of a joint U.S.-India approach toward the region. Due to these limitations, U.S.-India policies in Southeast Asia are expected to operate in parallel instead of becoming a joint endeavor.

\section{Policy Implications}

- The U.S. and India, which are at the initial stages of a cooperative approach to Southeast Asia, should intensify their diplomatic and military exchanges and establish a dedicated forum to exchange views and information on political and security developments in the region.

- Strengthening the regional security architecture should be a major focus of Indo-U.S. efforts in Southeast Asia. In particular, they should concentrate on assisting the creation of a region-wide maritime domain awareness system, as well as work in parallel to develop the capacity of partner militaries.

- Connectivity and infrastructure projects should be a renewed focus of Indian and U.S. efforts in the region, in partnership with like-minded third countries such as Japan. 
The transformation in U.S.-India relations from alienation during the Cold War to a robust strategic partnership is one of the most significant geopolitical development of recent decades. In June 2017, at Prime Minister Narendra Modi’s first meeting with President Donald Trump, the pair "resolved to expand and deepen the strategic partnership between the two countries and advance common objectives," most notably "promoting stability across the Indo-Pacific region."1 How likely is it that these two countries can actually cooperate and where is such cooperation most likely to happen? Across the subregions of the Indo-Pacific, Southeast Asia would appear to be an area where the transformation of Indo-U.S. strategic ties would have the most significant implications. For India, Southeast Asia is the most geographically proximate subregion and the focus of its efforts to both "Look East" and "Act East." For the United States, Southeast Asia historically has been a region where Washington's attention has ebbed and flowed. ${ }^{2}$ Under the Obama administration, however, both individual Southeast Asian nations and the Association of Southeast Asian Nations (ASEAN) as a whole received enhanced attention at the highest levels.

A decade ago, the idea of the United States and India working together in Southeast Asia would have appeared farfetched. Due to a growing recognition of a congruence of interests in the region, however, the two countries are increasingly articulating common diplomatic positions on key security challenges. Most

\footnotetext{
${ }^{1}$ Ministry of External Affairs (India), "U.S. India Joint Statement: Prosperity through Partnership," June 27, 2017, http://www.mea.gov.in/bilateraldocuments.htm?dt1/28560/Joint_Statement_United_States_and_India_Prosperity_Through_P artnership.

2 Joseph Chinyong Liow, Ambivalent Engagement: The United States and Regional Security in Southeast Asia after the Cold War (Washington, D.C.: Brookings Institution Press, 2017).
} 
prominently, the joint statement made after the Modi-Trump summit in 2017 addressed the maritime disputes in the South China Sea and reiterated "the importance of respecting freedom of navigation, overflight, and commerce throughout the region."3 This high profile diplomatic signal had been anticipated by some analysts who have long speculated about the close fit between the U.S. "rebalance" to Asia and India's "Act East" policy. ${ }^{4}$ Indeed, according to former U.S. defense secretary Ashton Carter, the United States focusing westwards and India acting to its east has resulted in a "strategic handshake" between the two nations and represents a "broad convergence of geopolitical interests" between the Indian and U.S. strategies. ${ }^{5}$

In particular, U.S. officials have been unusually vocal about the natural congruence between these two policies. In 2010, then assistant secretary of state for East Asian and Pacific Affairs Kurt Campbell argued that the United States is "strongly supportive of India playing a major role in the new architecture of the Asia-Pacific region."6 Two years later, defense secretary Leon Panetta echoed this

\footnotetext{
${ }^{3}$ Ministry of External Affairs (India), "U.S. India Joint Statement: Prosperity through Partnership"; and Elizabeth Roche, "Modi-Trump Statement Shows Convergence of Views on China," Live Mint, July 3, 2017, https://www.livemint.com/Politics/uBMwxBxa0VhuhQTnuNCqSP/ModiTrump-statementshows-convergence-of-views-on-China.html.

${ }^{4}$ Michael Kugelman and Raymond E. Vickery Jr., "From 'Looking' East to 'Acting' East: India's Own Pivot to Asia," The Diplomat, October 10, 2014, http://thediplomat.com/2014/10/fromlooking-east-to-acting-east-indias-own-pivot-to-asia/.

5 Jeff M. Smith, "Assessing U.S.-India Relations: The Strategic Handshake," The Diplomat, September 16, 2016, https://thediplomat.com/2016/09/assessing-us-india-relations-thestrategic-handshake/.

${ }^{6}$ Robyn Meredith, "America's Approach to Asia," Forbes, April 27, 2010, http://www.forbes.com/2010/04/27/asia-united-states-kurt-campbell-opinions-columnists-robynmeredith.html.
} 
view, calling defense cooperation with India the "linchpin" of the U.S. rebalance. ${ }^{7}$ Echoing this view, Significant continuities exist on this issue in the Trump administration, for example, where secretary of state Rex Tillerson proclaimed in 2017 that "India and the United States should be in the business of equipping other countries to defend their sovereignty, build greater connectivity, and have a louder voice in a regional architecture that promotes their interests and develops their economies. This is a natural complement to India's Act East policy."8 Indian officials have reciprocated, echoing the U.S. vision of a "free, open, and inclusive" Indo-Pacific—with Southeast Asia at the core—as an objective of regional policy. ${ }^{9}$ With officials in both countries noting, in the words of Indian foreign minister Sushma Swaraj, "a growing convergence of views between our countries, among others, on the Indo-Pacific," two key questions emerge Is the idea of a so-called natural fit between U.S. and Indian policies in Southeast Asia exaggerated? What are the practical limits to Indo-U.S. cooperation in the region?

In examining these questions, this article makes the following arguments. First, a convergence of interests is pushing the United States and India toward closer cooperation in Southeast Asia. For the time being, however, diplomatic consultations have yet to translate to operational policy coordination. Second, a

\footnotetext{
${ }^{7}$ Leon E. Panetta, "Partners in the 21st Century," June 6, 2012, available from Institute for Defence Studies and Analyses (IDSA), IDSA Key Speeches, http://www.idsa.in/keyspeeches/LeonEPanettaonPartnersinthe21stcentury.

${ }^{8}$ Rex Tillerson, "Defining Our Relationship with India for the Next Century," Center for Strategic and International Studies, October 18, 2017, https://www.csis.org/analysis/definingour-relationship-india-next-century-address-us-secretary-state-rex-tillerson.

${ }^{9}$ Sushma Swaraj, "Press Remarks on India-U.S. 2+2 Dialogue," Ministry of External Relations (India), September 6, 2018, https://www.mea.gov.in/Speeches-

Statements.htm?dtl/30357/EAMs+Press+Remarks+on+IndiaUS+2432+Dialogue.
} 
deepening of substantive cooperation between the two countries is constrained by a number of factors, including India's need to prioritize foreign policy challenges in its immediate region, concerns about provoking China, and a discomfort among countries in Southeast Asia with the idea of a joint U.S.-India approach to the region. Due to these limitations, U.S. and Indian policies in Southeast Asia are likely to continue to operate in parallel instead of becoming a true joint effort.

This topic is important for two reasons. First, Southeast Asia represents the most likely region for U.S.-Indian cooperation as there are no fundamental disagreements in either country's policy objectives. This is in sharp contrast to other parts of the world, such as the Middle East or Central Asia, where the two states have differing perspectives on Iran, Russia, dialogue with the Taliban, and a host of other issues. Consequently, Southeast Asia represents an ideal case study to begin to evaluate the potential and limitations of a U.S.-India "global partnership." 10 Second, as noted previously, a number of analysts and policymakers assume that there is a natural fit between Indian and U.S. regional policies. This article explicitly evaluates those assumptions, probing both the potential and limits of bilateral cooperation. This essay proceeds as follows:

- pp. XX-XX discusses the potential for the U.S. and India to cooperate in a different region.

- pp. XX-XX provide an overview of the United States' and India's interests and policies toward Southeast Asia.

\footnotetext{
10 The logic being that if the partnership cannot work here, it is unlikely to work elsewhere. On most-likely case design, see Jack S. Levy, "Qualitative Methods in International Relations," in Millennial Reflections on International Studies, M. Brecher and F. P. Harvey, eds. (Ann Arbor: University of Michigan Press, 2002) p. 442.
} 
- pp. XX-XX examine the convergence of interests between the two states and describe the manner in which they are working together.

- pp. XX-XX identify the limits to their cooperation.

- pp. XX-XX offer recommendations on strengthening Indo-U.S. cooperation in Southeast Asia and a brief conclusion.

\section{Cooperation in a Distant Land: The U.S. and India in Southeast Asia}

As noted in the introductory essay, there are three main motives for extraregional powers to cooperate in a different part of the world: (1) to prevent conflict escalation, (2) to work against an indigenous hostile regime, and (3) to jointly resist a third state's actions in the region. In the case of Southeast Asia, the chances of interstate war are remote, the United States and India do not oppose any of the existing regimes, and, to varying degrees, are comfortable with the regional political leaders. Instead, their main motivation to work together is to prevent the region from being dominated by a single hegemonic power. ${ }^{11}$ Although countries in Southeast Asia wish to avoid being caught up in it, the region is an emerging theater for great-power rivalry in Asia.

What sort of evidence would indicate a joint or convergent approach to a region by extraregional powers? First, one would expect to see an institutionalization of diplomatic talks and regular exchanges on developments in the region. As part of this, one would also find evidence of prior consultation before major diplomatic events. Second, regular military staff talks and bilateral visits to exchange views and perspectives on the region would occur on a consistent

\footnotetext{
${ }^{11}$ A similar aim is professed by other extraregional powers such as Australia and Japan.
} 
basis. If the partnership is at an advanced stage, then joint military exercises might also occur in the region. Finally, if there are economic complementarities, then one might expect to see close consultations on regional economic developments.

As explained later, the United States and India have regular diplomatic talks and exchanges of views with respect to Southeast Asia in various forums. Their militaries have regular staff talks and make frequent visits. The Indian and U.S. navies have engaged in some exercises in Southeast Asia, such as the Indonesianled Komodo naval exercises, which focus on humanitarian assistance and disaster relief. They have also exercised with Southeast Asian partners outside of the region, such as Singapore's participation in the 2007 Malabar naval maneuvers.. Moreover, the two states' militaries have participated in multilateral exercises under the ASEAN Defence Minsters' Meeting-Plus (ADMM-Plus) initiative. Finally, the U.S. and India have each independently articulated the need to enhance connectivity, especially between South and Southeast Asia. The two countries are increasingly speaking in the same language while expressing their apprehensions regarding the China's Belt and Road Initiative and the threat that Beijing's debt-trap diplomacy could pose to the autonomy of small states. ${ }^{12}$ In sum, there is growing evidence that Washington and New Delhi are converging with respect to their Southeast Asia policies. To understand where these convergences are happening, it is first necessary to understand the two countries' policies toward the region.

\footnotetext{
12 For a U.S. view, see Alex N. Wong, "Briefing on the Indo-Pacific Strategy," U.S. Department of State, Bureau of East Asian and Pacific Affairs, April 2, 2018, https://www.state.gov/r/pa/prs/ps/2018/04/280134.htm.
} 


\section{U.S. Interests and Policies toward Southeast Asia}

For much of the last century, U.S. policymakers have tended to see Southeast Asia as a vital conduit for pan-Asian trade, a font of economic opportunity, and a source of abundant natural resources that could alter the balance of power in East Asia if they fell into the wrong hands. ${ }^{13}$ From a historical standpoint, U.S. policy toward Southeast Asia has largely been reactive and shaped in key ways by the state of relations with other major powers, be it Japan in the 1930s, the Soviet Union and China during the Cold War, or China alone today. Consequently, Southeast Asia itself is often seen as an afterthought in U.S. Asia policy, leading critics to allege that an inattentive Washington has repeatedly failed to identify its priorities there and instead been forced to improvise policies in response to crises of the moment rather than adhere to a coherent strategy. ${ }^{14}$ With Southeast Asia at the heart of the rebalance strategy, the Obama administration may have been an interlude in this traditional pattern. The significant time and personal attention that President Obama devoted to the countries of the region, however, has not led to a permanent change. Rejecting the Trans-Pacific Partnership trade negotiations within days of taking office, the Trump administration undercut U.S. claims to economic leadership in Asia and renewed concerns about the U.S. commitment to the region and its reliability as a partner. ${ }^{15}$ For their part, many

\footnotetext{
${ }^{13}$ Melvyn P. Leffler, "The American Conception of National Security and the Beginnings of the Cold War, 1945-48," American Historical Review 89, no. 2 (1984): 359.

${ }^{14}$ Diane K. Mauzy and Brian L. Job, "U.S. Policy in Southeast Asia: Limited Re-engagement after Years of Benign Neglect,” Asian Survey 47, no. 4 (July/August 2007): 622-41.

15 Joseph Chinyong Liow, "U.S.-Southeast Asia Relations under the Trump Administration," Asia Policy, no. 24 (July 2017): 57.
} 
states in Southeast Asia remain unconvinced that the region plays a central role in the new administration's "free and open Indo-Pacific" concept, leading them to seek partnerships with countries such as Japan, India, and Australia.

Contemporary U.S. interests in Southeast Asia remain in line with their historical antecedents. The region continues to be a vital transit corridor connecting the Indian Ocean to the Pacific. Two-thirds of the world's oil and nearly $\$ 5$ trillion in goods pass through the waterways of Southeast Asia on an annual basis. The same sea lanes are also used by the U.S. Navy and other militaries to project power around the globe. In the economic sphere, the United States is already the main source of foreign direct investment in Southeast Asia by a substantial margin. ${ }^{16}$ With a collective middle class that is roughly the size of the entire U.S. population, Southeast Asia is likely to grow in importance for the United States as a market for both investment and as exports. Indeed, with China appearing to enter into a protracted period of economic slowdown, Southeast Asia could re-emerge as a key driver of the global economy. In the security realm, Washington is still averse to seeing the region fall under the sway of a hostile power. In the recent past, Southeast Asia has been an important outpost for groups like al Qaeda and the Islamic State of Iraq and Syria (ISIS). Given that many security challenges in Southeast Asia are emerging from within states, rather than between them, the United States is interested in containing the spread of violent extremism. Washington is also concerned about mitigating any potential political volatility triggered by China's rise. The ultimate aim of U.S.

\footnotetext{
${ }^{16}$ David Shambaugh, "U.S.-China Rivalry in Southeast Asia: Power Shift or Competitive Coexistence?" International Security 42, no. 4 (2018): 106.
} 
regional policy is to see the emergence of a stable and peaceful Southeast Asia where the centuries-old principle of the freedom of the seas is sustained and existing territorial disputes are resolved lawfully and without coercion.

\section{India's Act East Policy}

In 2018 , on the 25th anniversary of the India-ASEAN dialogue partnership, Prime Minister Modi took the unprecedented step of inviting all ten regional leaders to be the guests of honor at India's Republic Day parade. Southeast Asia has been an important element in India's global diplomacy ever since the government of P.V. Narasimha Rao initiated its Look East policy in 1991. Now known as Act East under the Modi administration, this policy has consistently sought to bolster economic ties and strategic linkages with countries of East Asia in general and Southeast Asia in particular. ${ }^{17}$

The first factor driving India's interest in Southeast Asia is the potential opportunities the region offers for India's socio-economic development. ASEAN is India's fourth largest trading partner (after China, the United States, and the United Arab Emirates)—with bilateral trade exceeding $\$ 70$ billion—as well as a

\footnotetext{
${ }^{17}$ Apart from Southeast Asia, India's Act East policy includes relations with Japan, Korea, and Australia. See "Act East Policy," Ministry of External Affairs (India), Press Information Bureau, December 23, 2015, http://pib.nic.in/newsite/PrintRelease.aspx?relid=133837. For examples of the vast and growing literature on India's engagement with Southeast Asia, see Amitav Acharya, East of India, South of China: Sino-Indian Encounters in Southeast Asia (New Delhi: Oxford University Press, 2017); Frédéric Grare, India Turns East: International Engagement and U.S.-China Rivalry (New York: Oxford University Press, 2017); Isabelle de Saint-Mezard, "India and Southeast Asia: Whither India's Strategic Engagements with ASEAN?" in Engaging the World: Indian Foreign Policy since 1947, ed. Sumit Ganguly (New Delhi: Oxford University Press, 2016), 326-51; and Rouble Sharma, Dynamics of Cooperation between India-ASEAN since 2000 (New Delhi: Manak Publications, 2015).
} 
significant source of FDI. ${ }^{18}$ Infrastructure and digital connectivity is an important aspect of these relations. Many in India argue that the best way to address the endemic poverty and underdevelopment of the country's northeastern states is to enhance their ties-geographic, economic and cultural—with neighboring countries in Southeast Asia. ${ }^{19}$

The second reason the region garners India's attention is the diplomatic and strategic advantages that Southeast Asia offers. In contrast to Beijing, New Delhi has gained considerable diplomatic mileage with its peaceful engagement of both ASEAN and individual Southeast Asian states. For their part, Southeast Asian countries have welcomed security cooperation with India, especially in the naval domain, as the presence of multiple major powers in the region reduces the likelihood that any single one could dominate. ${ }^{20}$ The recognition that India has a legitimate role to play in the region has, in turn, helped build up New Delhi's status as a major power in Asia. ${ }^{21}$ Finally, in so far as India's Act East policy is in

\footnotetext{
18 Ministry of External Relations (India), "ASEAN-India Relations," http://mea.gov.in/aseanindia/20-years.htm.

${ }^{19}$ Press Trust of India, "Act East: Centre Plans to Link North East India to South East Asia, Says Assam Governor Jagdish Mukhi," Indian Express, November 26, 2017, https://indianexpress.com/article/india/act-east-centre-plans-to-link-north-east-india-to-southeast-asia-says-assam-governor-jagdish-mukhi-4955476/.

${ }^{20}$ Walter C. Ladwig III, 'Delhi's Pacific Ambition: Naval Power, 'Look East,' and India's Emerging Role in the Asia-Pacific," Asian Security 5, no. 2 (2009): 94-95; C. Raja Mohan, Samudra Manthan: Sino-Indian Rivalry in the Indo-Pacific (Washington, D.C.: Carnegie Endowment for International Peace, 2012), 94-108.

${ }^{21}$ The transformation in U.S.-India relations played a key role in facilitating Southeast Asian acceptance of India as an extraregional actor.
} 
part a response to China's growing influence in Asia, and an active presence in Southeast Asia gives India some leverage vis-à-vis its relationship with China. ${ }^{22}$

\section{Working Together: The Convergence of Interests}

Despite occasional disagreements-primarily over engagement with the military junta in Myanmar-there is a broad convergence of Indo-U.S. diplomatic positions in Southeast Asia. As recognition of the range of shared objectives has become clearer, Indian strategists have called for a deepening of bilateral ties, both as a response to the aggressive rise of China and to further India's interests. Describing the structural factors pushing the two countries together, Rajesh Rajagopalan has argued that

China's rise and aggressive behavior, coupled with the massive imbalance of power between China and India, leaves India with little choice but to attempt to balance China....Though the United States can probably still counter China by itself, it would be a lot easier to do this in concert with other Asian powers such as India. This strategic picture suggests significant promise for U.S.-India relations in the longer term. ${ }^{23}$

To be fair, there are some Indian pundits and commentators who caution against growing ties with United States. These skeptics raise concerns about U.S. reliability and trustworthiness or express ideologically-rooted suspicion of

${ }^{22}$ Tan Tai Yong, "India-ASEAN Relations at Seventy," in Seven Decades of Independent India: Ideas and Reflections, ed. Vinod Rai and Amitendu Palit (New Delhi: Penguin India, 2018), 55.

${ }^{23}$ Rajesh Rajagopalan, "U.S.-India Relations under President Trump: Promise and Peril, Asia Policy," Asia Policy, no. 24 (2017): 39. See also Harsh V. Pant and Yogesh Joshi, "Indo-U.S. Relations under Modi: The Strategic Logic Underlying the Embrace," International Affairs 93, no. 1 (2017); 141-45; and Dhruva Jaishankar, "India and the United States in the Trump Era: Re-Evaluating Bilateral and Global Relations," Brookings Institution, Brookings Policy Paper, no. 37, June 2017, 12-13, 20-21. 
American intentions. ${ }^{24}$ These minority views, however, are increasingly out of step

with both mainstream public opinion and the policy of successive governments, which have favored closer ties with the United States. The Naresh Chandra Committee, established in 2012 to evaluate India's internal and external challenges, for example, forthrightly argued that

the growing strategic partnership with the U.S., based on a convergence of interests, especially in the Asia Pacific region (including the Indian Ocean), offer opportunities for strengthening our national security capacity and capabilities, shape the global security architecture and seek greater U.S. coordination with us. ${ }^{25}$

In sum, there is a growing consensus, both within the Indian government and in the broader strategic community that partnering with the United States in the Asia-Pacific is a logical long-term strategy for India. ${ }^{26}$

Such sentiments are mirrored by U.S. assessments. According to a recent RAND study, for example,

At the regional level, the two nations share fundamental goals including IndoPacific stability; secure shipping through the Malacca Straits; increased land, sea, and air connectivity infrastructure; and peaceful settlement of territorial

\footnotetext{
${ }^{24}$ M.K. Bhadrakumar, "For Modi's India, $2+2=0$ as Trump Tightens the Leash," South China Morning Post, September 7, 2018, https://www.scmp.com/week-

asia/geopolitics/article/2163310/modis-india-220-trump-tightens-leash; and Bharat Karnad, "New Delhi Must Reset Its Overt Tilt to the U.S.," Hindustan Times, July 17, 2018, https://www.hindustantimes.com/analysis/new-delhi-must-reset-its-overt-tilt-to-the-us/storyT0Tc65MTTtLY4dVoOLrkqI.html.

${ }^{25}$ National Security Council Secretariat (India), Report of the Task Force on National Security (New Delhi, 2012), section 2.31, 10. (Otherwise known as the Naresh Chandra Committee Report.)

${ }^{26}$ For example, see Samir Saran and S. Paul Kapur, How India and the US can lead in the IndoPacific, The Interpreter, August 18, 2017, https://www.lowyinstitute.org/the-interpreter/howindia-and-us-can-lead-indo-pacific; Indrani Bagchi, "Two plus two tango: Despite President Trump's hollering, US-India ties have actually thrived on his watch," The Times of India, September 10, 2018; Joint Task Force Report, The United States and India: Forging an Indispensable Democratic Partnership (Washington DC: Center for American Progress, January 2018); Abhijit Singh, et. al, The New India-US Partnership in the Indo-Pacific: Peace, Prosperity and Security (New Delhi: Observer Research Foundation, 2018); Gautam Banerjee, "US-India 2 Plus 2 Dialogue: Significance of Strategic Partnership," (New Delhi: Vivekananda International Foundation, 2018).
} 
disputes. At the country level, they share the goals of encouraging Myanmar's democratic transition; containing radicalism in Indonesia and Malaysia; increasing Vietnam's external engagement; and ensuring that Thailand, Singapore, and the Philippines maintain their traditional relationships. ${ }^{27}$

As in India, these assessments from the strategic community reflect official thinking. In 2013, the U.S. national security adviser, Thomas Donilon, directly addressed the synergies between the two nation's policies, noting that "U.S. and Indian interests powerfully converge in the Asia-Pacific, where India has much to give and much to gain. Southeast Asia begins in Northeast India, and we welcome India's efforts to 'look East,' from supporting reforms in Burma to trilateral cooperation with Japan to promoting maritime security." 28 The Trump administration's first National Security Strategy, issued in December 2017, offered a similar perspective, welcoming "India's emergence as a leading global power and stronger strategic and defense partner," in the Indo-Pacific and pledging to "support India's growing relationships throughout the region." 29

\section{Diplomatic Interests}

Perhaps for the first time, the United States and India are in a position wherein they agree on most issues pertaining to Southeast Asia. As a result, their diplomats are increasingly speaking the same language. Most significantly, the

\footnotetext{
27 Jonah Blank, Jennifer D. P. Moroney, Angel Rabasa, and Bonny Lin, Look East, Cross Black Waters: India's Interest in Southeast Asia (Santa Monica: RAND Corporation, 2015), xv-xvi.

28 Tom Donilon, "Remarks by Tom Donilon, National Security Advisor to the President: 'The United States and the Asia-Pacific in 2013," Asia Society, New York, March 11, 2013, https://obamawhitehouse.archives.gov/the-press-office/2013/03/11/remarks-tom-donilonnational-security-advisor-president-united-states-an.

${ }^{29}$ White House, National Security Strategy of the United States of America, (Washington, D.C., 2017), 46-47, https://www.whitehouse.gov/wp-content/uploads/2017/12/NSS-Final-12-18-20170905.pdf.
} 
September 2014 joint statement by then President Barack Obama and Prime

Minister Modi referred directly to tensions in Southeast Asia and stated that:

\begin{abstract}
The leaders expressed concern about rising tensions over maritime territorial disputes, and affirmed the importance of safeguarding maritime security and ensuring freedom of navigation and over flight throughout the region, especially in the South China Sea. The Prime Minister and President called on all parties to avoid the use, or threat of use, of force in advancing their claims...[and] urged the concerned parties to pursue resolution of their territorial and maritime disputes through all peaceful means, in accordance with universally recognized principles of international law, including the United Nations Convention on the Law of the Sea. ${ }^{30}$
\end{abstract}

These same themes were repeated in the communique issued after Modi's June 2017 visit to Washington, with the added note that "as responsible stewards in the Indo-Pacific region, President Trump and Prime Minister Modi agreed that a close partnership between the United States and India is central to peace and stability in the region." 31

Such high-profile diplomatic signaling is the result of repeated deliberations between policy-makers in both countries who have, over the years, engaged in an unprecedented level of discussion about the Asia-Pacific region. Though prior consultations have occurred sporadically, since the start of the East Asia Dialogue in 2010 the two sides have had an extant forum for regular, high-level discussions about developments in East and Southeast Asia. According to a former U.S. official who participated in these bilateral exchanges, the consultations involved a variety of activities ranging from "how to coordinate policies in multilateral forums" to "exchanging views about the rise of China and maritime disputes in the South

\footnotetext{
30 Ministry of External Affairs (India), "Joint Statement during the Visit of Prime Minister to USA," September 30, 2014, http://www.mea.gov.in/bilateraldocuments.htm?dtl/24051/Joint_Statement_during_the_visit_of_Prime_Minister_to_USA.

${ }^{31}$ Ministry of External Affairs (India), "U.S. India Joint Statement: Prosperity through Partnership."
} 
China Sea."32 In 2016 the two countries also initiated a maritime security dialogue - which served as an additional forum for exchanging views on AsiaPacific maritime developments—at the assistant secretary/joint secretary level. ${ }^{33}$ Both sides, however, are quick to point out that these talks are not aimed at any third country. According to an unnamed U.S. participant, "we all want to work together in concert to ensure rules-based arbitration of international disputes... No one is isolating anyone. There is no containment taking place here. This is about constructive engagement all around the region." 34 Such remarks eschewing any intention to "contain" a third power were aimed at reassuring China about the benign nature of these dialogues.

With changes in governments in both New Delhi and Washington in 201516, some of these initiatives fell by the wayside. Reflecting turbulence in staffing and the general policy uncertainty in the early months of the Trump administration, for a time there were just sporadic consultations between the two bureaucracies. More recently, however, the Trump administration has taken a different approach to U.S.-India relations than its predecessor. Under the Obama administration, there were roughly 30 bilateral dialogues between the two states covering a range of topics. To some critics, this amounted to little more than an

\footnotetext{
${ }^{32}$ Author interview with a former U.S. government official, Washington D.C., November 18, 2014.

${ }^{33}$ For more on the various defense dialogues between the U.S. and India, see Table 1 in Cara Abercrombie, "Realizing the Potential: Mature Defense Cooperation and the U.S.-India Strategic Partnership," in this special issue. There were additional dialogues during the Obama administration, for instance on climate change and on cyber, but those are beyond the scope of this article.

34 "India, U.S. Working to Ensure No Disruption to Peace in East Asia," Economic Times, April 14, 2014, https://economictimes.indiatimes.com/news/politics-and-nation/india-us-working-toensure-no-disruption-to-peace-in-east-asia/articleshow/33736537.cms.
} 
endless series of "talk about talks" that achieved few substantial outcomes. The Trump administration, in contrast, signaled a desire to focus on only a few, select issue areas. Accordingly, in August 2017, Trump and Modi, announced a " $2+2$ " ministerial dialogue involving just the foreign and defense ministries "in a bid to shift bilateral ties to a higher strategic plane." ${ }^{35}$ In the first iteration of the $2+2$, held in September 2018, the two sides concluded the long-pending Communications Compatibility and Security Agreement that will allowing their militaries to share data in real time via specialized secure communications systems rather than the commercial hardware India currently uses. From a diplomatic perspective, what was more significant was the language in the joint statement issued at the meeting, which argued that both countries are "committed to work together and in concert with other partners toward advancing a free, open, and inclusive Indo-Pacific region, based on recognition of ASEAN centrality and on respect for sovereignty, territorial integrity, rule of law, good governance, free and fair trade, and freedom of navigation and overflight." 36 Such strong diplomatic language alluding to China's expansive territorial claims in the South China Sea, unfair trade practices and efforts to undermine ASEAN clearly indicates shared interests and concerns in both New Delhi and Washington.

\footnotetext{
${ }^{35}$ Elizabeth Roche, "New Dialogue Format to Help Shift India-U.S. Ties to a Higher Plane," Live Mint, August 18, 2017, https://www.livemint.com/Politics/hrsSAywXTBqsuGD2uzn7TO/Newdialogue-format-to-help-shift-IndiaUS.html. See also Dhruva Jaishankar, "2+ 2 Delay Does Not Mean India-U.S. Ties Are in Trouble," NDTV News, June 29, 2018, https://www.ndtv.com/opinion/5-facts-that-prove-india-us-defence-ties-are-growing-1874850.

${ }^{36}$ Ministry of External Affairs (India), "Joint Statement on the Inaugural India-U.S 2+2 Ministerial Dialogue," September 6, 2018, https://www.mea.gov.in/bilateraldocuments.htm?dtl/30358/Joint_Statement_on_the_Inaugural_IndiaUS_2432_Ministerial_Dial ogue.
} 


\section{Security Interests}

In the security realm, the United States and India have rarely cooperated directly in Southeast Asia. ${ }^{37}$ Driven by convergent regional goals, however, the two countries are working in parallel to support the armed forces of partner states. ${ }^{38}$ In undertaking these efforts, both countries are pursuing a common aim: to enhance the capacity of, and foster friendly ties with, regional militaries. This is best exemplified in the case of Singapore, which has extensive defense ties with both Washington and New Delhi. The United States' long-standing military cooperation with Singapore allows the U.S. Navy to base a logistical unit on the island and to operate resupply vessels from its ports, as well as position U.S. naval vessels there on a rotational basis. The U.S. frequently deploys ships and planes to the city state, and the armed forces of the two countries undertake a range of bilateral and multilateral exercises. ${ }^{39}$ Recently, India has taken its naval cooperation with Singapore to another level with the signing of the IndiaSingapore Bilateral Agreement for Navy Cooperation in November 2017. This agreement allows Indian naval ships to be replenished at Changi Naval Base and thereby operate for longer periods in the South China Sea.

\footnotetext{
${ }^{37}$ The notable exceptions were when Indian ships escorted U.S. naval ships through the Strait of Malacca following the attacks on the twin towers in 2001 and during joint relief operations in the wake of the 2004 Indian Ocean Tsunami. Apart from these instances, the navies of the two countries have conducted joint exercises in the Pacific Ocean. See David Scott, "The 'IndoPacific'-New Regional Formulations and New Maritime Frameworks for U.S.-India Strategic Convergence," Asia-Pacific Review 19, no. 2 (2012): 98-100.

${ }^{38}$ For more on the security convergence between the United States and India in the Indo-Pacific, see Scott, "The 'Indo-Pacific.”

${ }^{39}$ Daniel Chua Wei Boon, "Singapore-U.S. Defense Relations: Enhancing Security, Benefiting Region," Straits Times, December 9, 2015.
} 
Beyond Singapore, both New Delhi and Washington are deepening defense ties with other countries in Southeast Asia, with varying degree of success. ${ }^{40} \mathrm{In}$ 2016, India and Vietnam upgraded their relationship to that of a comprehensive strategic partnership, and New Delhi offered Hanoi $\$ 500$ million in credit to fund the modernization and expansion of the Vietnamese armed forces. ${ }^{41}$ In an important effort to help Vietnam develop the ability to protect its territory, the Indian Navy has trained its Vietnamese counterparts to operate advanced Kiloclass submarines that Hanoi acquired from Russia. The Indian Air Force has offered similar instruction for Vietnamese pilots in operating the Russian-built Sukhoi Su-30 multirole fighter. In January 2018, the two armies held their first joint exercise in India and, more recently, in May 2018, three ships from the Indian navy held joint maneuvers with their Vietnamese counterparts in the South China Sea for the first time. ${ }^{42}$ The United States and Vietnam are also slowly reaching out to one another. In 2016, the Obama administration lifted a fifty-year-old arms embargo on Vietnam. This followed efforts to forge a bilateral security relationship, including the establishment of a regular forum for direct military-tomilitary talks and the initiation of joint noncombat naval exercises. In January

\footnotetext{
${ }^{40}$ For more on India's defense ties with ASEAN countries see Ladwig, "Delhi's Pacific Ambition," 96-98. For views on U.S. ties with the region see Donald E. Weatherbee, "Political Change in Southeast Asia: Challenges for U.S. Strategy," in Strategic Asia 2007-08: Domestic Political Change and Grand Strategy, ed. Ashley Tellis and Michael Wills (Seattle: National Bureau of Asian Research, 2007), 235-65; and Shambaugh, "U.S.-China Rivalry in Southeast Asia."

41 "India, Vietnam Sign Defense Agreements to Counter China," NDTV.com, September 3, 2016, https://www.ndtv.com/india-news/india-vietnam-sign-defense-agreements-to-counter-china1454059; and Harsh V. Pant, "India and Vietnam: A "Strategic Partnership" in the Making," S. Rajarathnam School of International Studies (RSIS), RSIS Policy Brief, April 2018.

42 Raju Gopalakrishnan, "India is Pushing to Be a Bigger Player in Southeast Asia, and It's a Clear Challenge to China," Business Insider, June 3, 2018, http://www.businessinsider.com/rwith-ports-ships-and-promises-india-asserts-role-in-southeast-asia-2018-6/?IR=T.
} 
2018, a U.S. aircraft carrier made a port call to Da Nang for the first time since the end of the Vietnam War. . The U.S. military has also transferred a dozen patrol boats and a secretary-class cutter to the Vietnam Coast Guard. Recently enacted U.S. sanctions on countries purchasing arms from Russia poses a challenge to deepening military cooperation with Hanoi. ${ }^{43}$ Nevertheless, if Vietnam continues to feel threatened by China, it is possible that it will strengthen its defense relations with both India and the United States.

With the rest of the ASEAN countries, both India and the U.S. have had varying levels of success in developing defense relationships. Ristian Atriandi Supriyanto classifies India's defense cooperation with the ten ASEAN states into three categories: probing, developmental, and advanced. ${ }^{44}$ According to this framework, India is at an early stage of defense cooperation, probing, with five of the ten: Brunei, Cambodia, Myanmar, Philippines, and Timor Leste. Defense ties are somewhat closer, classified as developmental, with four other countries: Indonesia, Malaysia, Thailand, and Vietnam. Only Singapore can be classified at

\footnotetext{
${ }^{43}$ Ian Storey, "US Assault on Russian Arms Exports Could Misfire in Asia," Nikkei Asian Review, November 21, 2018, https://asia.nikkei.com/Opinion/US-assault-on-Russian-arms-exportscould-misfire-in-Asia; Le Hong Hiep, "Why did Vietnam Cancel its Defence Engagements with the US?" ISEAS Commentary, December 11, 2018, https://www.iseas.edu.sg/medias/commentaries/item/8691-why-did-vietnam-cancel-its-defenceengagements-with-the-us-by-le-hong-hiep.

${ }^{44}$ Ristian Atriandi Supriyanto, "A Sea of Opportunity: Southeast Asia's Growing Naval Cooperation with India," in India's Naval Strategy and Asian Security, ed. Anit Mukherjee and C. Raja Mohan (New York: Routledge, 2015), 192-214. For more on India's military ties with the region see Satu Limaye, "Weighted West, Focused on the Indian Ocean and Cooperating across the Indo-Pacific: The Indian Navy's New Maritime Strategy, Capabilities, and Diplomacy," CNA, April 2017), 45-49; Grare, India Turns East, 77-88; Ajaya Kumar Das, ed., India-ASEAN Defence Relations, RSIS monograph no. 28 (Singapore: RSIS, 2013); and Sasiwan Chingchit, From Looks to Action: Thailand-India Strategic Convergence and Defence Cooperation, IDSA, Occasional Paper no. 40, 2015.
} 
an advanced stage since both countries hold regular dialogues and have signed numerous defense cooperation agreements. ${ }^{45}$

The United States retains a robust program of military exchanges, defense sales, and joint training programs with the majority of Southeast Asian states. 46 Malaysia was one of the emerging partners embraced by the Obama administration as part of its rebalance strategy and Washington has a healthy security relationship with Kuala Lumpur, although it is purposefully downplayed due to domestic sensitivities in the Muslim-majority nation.. The Malaysian military sends dozens of officers annually to professional education programs in the United States, the two countries' armies and navies regularly conduct bilateral and multilateral military exercises, and the U.S. Navy visits Malaysian ports for resupply and maintenance. Washington was able to cultivate warm ties with Kuala Lumpur under the Najib Razak government, which prioritized good relations with United States, however, the return to power of Mahathir Mohamad-a vocal opponent of including outside powers such as the United States and Australia in pan-Asian regional groupings-raises questions for the future.

A treaty ally of United States, the Philippines is the largest recipient of U.S. foreign military assistance in the region. The U.S. aim is to help the Philippine

45 Prashanth Parameswaran, "Why the New India-Singapore Naval Pact Matters," Diplomat, November 30, 2017, https://thediplomat.com/2017/11/why-the-new-india-singapore-naval-pactmatters/.

${ }^{46}$ Myanmar is the only country in the region not to send military officers to U.S. professional military education programs and Myanmar, Cambodia, and Laos are the only ones who do not participate in the U.S. Foreign Military Sales and Financing Program. Shambaugh, "U.S.China Rivalry in Southeast Asia," 111. 
Armed Forces reorient from domestic security to external threats, as well as to enhance their ability to monitor their extensive maritime territory. Although the U.S. military no longer maintains permanent bases in the islands, U.S. aircraft,ships, and soldiers operate from a country an a rotational basis. Despite widespread public support for a close relationship with the United States, U.S.Philippine relations hit a rough patch during the early years of the Duterte administration. In recent months, however, bilateral relations appear to be on an upswing, as Philippine president appears to have found a kindred spirit in Trump.

Although neither U.S. nor Indian officials publicly admit it, the main intention behind these endeavors is to show their presence in the region, both to reassure partners and to provide a degree of balance against China's growing influence. While doing so, they are also sending a signal that they attach importance to the freedom of navigation and the freedom of the seas. There is little evidence, though, of any direct coordination between the Indian and U.S. militaries in these activities in Southeast Asia. At the same time, the transformation in U.S.-India ties-particularly in their defense relations-has resulted in considerable bonhomie between the two militaries. This familiarity and the intense dialogues accruing from frequent interactions has resulted in greater bilateral discussions about regional and extra-regional affairs. According to a senior U.S. official, both countries have identified two avenues for future cooperation that are pertinent to Southeast Asia: maritime domain awareness (MDA) and capacity-building in partner countries. ${ }^{47}$ The latter suggests that, in

\footnotetext{
${ }^{47}$ Author interview, New Delhi, December 19, 2014.
} 
the future, the United States and India may actively coordinate their efforts to enhance the capacity of partner militaries in the region.

\section{Economic Interests}

In terms of regional economic policy, the United States and India are committed to the connectivity strategy linking South and Southeast Asia. This approach is based on the premise that joining these two regions through an economic and infrastructure corridor is in the interests of both India and the United States. India's development agenda would be facilitated by physically linking its poverty-stricken northeastern region to one of the fastest growing set of economies in the world. Such connections would also allow India to assume a more central position in Asia's economic architecture, which would in turn contribute to enhancing the prosperity and security of the continent. In this vein, in 2011, then prime minister Manmohan Singh declared physical connectivity between India and ASEAN to be a "strategic objective". ${ }^{48}$ Echoing a similar view, U.S. State Department officials have argued that connecting the two regions will enhance security and prosperity in Asia-which is in the overall interests of the United States. ${ }^{49}$ This is not just an altruistic endeavor, however, as there is an expectation that "additional infrastructure links and better trade relations

\footnotetext{
48 B. Muralidhar Reddy, "India-ASEAN Connectivity Is Our Strategic Objective, Says Manmohan," Hindu, November 20, 2011, http://www.thehindu.com/news/national/indiaaseanconnectivity-is-our-strategic-objective-says-manmohan/article2641786.ece.

${ }^{49}$ Fatema Z. Sumar, "Shaping the Future of Trade and Connectivity in the Indo-Pacific," remarks at the CII Kolkata Business Luncheon, May 8, 2014.
} 
[between the two regions] would also help unlock and expand existing markets for

U.S. goods and services." 50

While enhancing connectivity between these two areas will be beneficial for all states in the region, an unstated goal is to create a counterbalance to China. Indo-U.S. connectivity projects offer an alternative to Beijing's efforts to connect southern China with Southeast Asia "to advance regional economic integration and promote greater economic reliance on China." ${ }^{51}$ Owing to China's economic weight and a perception of its growing assertiveness, most ASEAN countries welcome a more robust Indian role in the region, even though China's trade with ASEAN is approximately five times that of India. ${ }^{52}$ Connectivity, therefore, not only has an economic but also a geopolitical rationale. Despite shared visions for regional economic development, however, as discussed in the next section, there are limitations to U.S.-India cooperation in the region.

\section{Limits to Cooperation}

Despite the positive transformation in bilateral ties and a convergence of regional objectives, there are five major constraints to Indo-U.S. cooperation in Southeast Asia. First, important policy challenges foreign and domestic, closer to home limit India's ability to play a robust role east of Malacca. Although successive

\footnotetext{
50 Ted Osius, "Connectivity's Benefits and Challenges," in Enhancing India-ASEAN Connectivity, ed. Ted Osius (Washington, D.C.: CSIS, 2013), 20. This report provides a good overview of issues relating to India-ASEAN connectivity.

51 Joshua P. Meltzer, "China's One Belt One Road initiative: A View from the United States," Asan Institute for Policy Studies, ASAN Forum, June 19, 2017, http://www.theasanforum.org/a-view-from-the-united-states-2/.

52 Tan, "India-ASEAN Relations at Seventy," 50-56; and Grare, India Turns East, 72-75.
} 
governments have endorsed the Look/Act East policy, the priority for both time and resources is necessarily given to the unresolved territorial disputes on India's land borders with Pakistan and China. ${ }^{53}$ Within the country, armed violence in the northeast and Kashmir has at times proven to be beyond the ability of local police to contain. ${ }^{54}$ To guard against Pakistani revisionism and Chinese adventurism, as well as support local authorities in domestic contingencies, India is compelled to retain a large conventional army that absorbs $55 \%$ of the country's defense spending. ${ }^{55}$ This puts a significant constraint on the growth and development of the branch of the armed forces which is most relevant in Southeast Asia: the navy. The Indian Navy has always been the so-called Cinderella service, receiving the smallest budgetary allocation of the armed forces. ${ }^{56}$ Although the Indian Navy has embraced the self-designated role as a "net security provider" in the Indian Ocean, its focus is more toward the Persian Gulf, Arabian Sea, and Bay of Bengal-India's immediate neighborhood-rather than toward Southeast Asia. ${ }^{57}$ Moreover, at present, the navy lacks the capacity to operate effectively in

${ }^{53}$ Arzan Tarapore, "India's Slow Emergence as a Regional Security Actor," Washington Quarterly 40, no. 2 (2017): 169-70.

${ }^{54}$ Paul Staniland, "America Has High Expectations for India. Can New Delhi Deliver?" War on the Rocks, February 22, 2018, https://warontherocks.com/2018/02/america-has-highexpectations-for-india-can-new-delhi-deliver.

${ }^{55}$ Defense spending figures taken from Laxman Kumar Behera, "Defence Budget 2018-19: The Imperative of Controlling Manpower Cost," IDSA, Issue Brief, February 5, 2018, 5. For the dominance of the continental mindset in the Indian armed forces, see John H. Gill, "Challenges for India's Military Strategy: Matching Capabilities to Ambitions?” in Strategic Asia 2017-18: Power, Ideas, and Military Strategy in the Asia-Pacific, ed. Michael Wills, Alison Szalwinski, and Ashley J. Tellis (Seattle: National Bureau of Asian Research, 2017).

${ }^{56}$ For an overview of the Indian navy and the challenges to its growth, see Walter C. Ladwig III, "Drivers of Indian Naval Expansion," in The Rise of the Indian Navy: Internal Vulnerabilities, External Challenges, ed. Harsh Pant (Oxford: Ashgate, 2012), 19-40.

${ }^{57}$ Limaye, Weighted West; and Prakash Panneerselvam, "Maritime Component of ChinaPakistan Economic Corridor (CPEC): India-China Competition in the Arabian Sea," Maritime 
Southeast and East Asia. According to Gurpreet Khurana, in the waters east of the Strait of Malacca, "the extended logistic lines and choke-points together pose a substantial hindrance for the [navy] to undertake missions across the spectrum of conflict." 58 As Chinese influence among the smaller nations of South Asia continues to grow, the time and attention of India's foreign and security policy elites will be increasingly devoted to the immediate neighborhood. Southeast Asia will have to compete with the Persian Gulf for any diplomatic and military resources that remain after attending to issues closer to home.

A second factor constraining Indo-U.S. cooperation is a fear in New Delhi, and to a lesser extent in Washington, that cooperation might adversely affect bilateral relations with China. The economies of India, China, and the United States are interdependent. Despite some political tensions, all three countries seek expanded economic growth, and none explicitly seeks to create an enemy of the other. In the recent past, the United States has been more willing than India to balance economic cooperation with selected confrontation in its China policy. The Obama administration, for example, could negotiate a bilateral investment treaty with China while also increasing the pace of freedom of navigation operations in the South China Sea in defiance of Beijing's maritime claims around its artificially created land features. Unlike the United States, India shares a disputed land border with China. Thus, India has been more sensitive to Beijing's diplomatic

\footnotetext{
Affairs: Journal of the National Maritime Foundation of India 13, no. 2 (2017): 44-46. For more on the Indian Navy and its concept of net security provider, see Anit Mukherjee, "India as a Net Security Provider: Concept and Impediments," RSIS Policy Brief, August 2014, https://www.rsis.edu.sg/wp-content/uploads/2014/09/PB_140903_India-Net-Security.pdf.

${ }^{58}$ Gurpreet S. Khurana, "India's Maritime Strategy: Context and Subtext," Maritime Affairs: Journal of the National Maritime Foundation of India 13, no. 1 (2017): 20.
} 
posturing and readiness to take offence at any action perceived to be aimed at containing its rise. Although some analysts have exaggerated the substantive effect that the so-called Wuhan summit had on Sino-Indian relations in the wake of the 2017 Doklam standoff, there has been a clear effort by the Modi administration to pause the growing antagonism in the bilateral relationship. ${ }^{59} \mathrm{In}$ the near future, India can be expected to continue to carefully adjust its policy in Southeast Asia to ensure that it does not negatively affect either its trade relationship with China or its own territorial dispute. ${ }^{60}$ For its part, the United States wants the countries of Southeast Asia to be able to defend themselves against intimidation and aggression. Despite what Aaron Friedberg terms the Trump administration's "unprecedentedly combative stance towards China," Washington does not want to be drawn into a conflict over a peripheral disputed territory where a minor disagreement could become a major war. ${ }^{61}$ To allay such fears and to safeguard their bilateral ties with China, both Washington and New Delhi are careful in calibrating their relationship in Southeast Asia.

Third, there is an important institutional mismatch that prevents greater cooperation between the two democracies. The limited capacities of India's foreign and security bureaucracies constrains New Delhi's ability to play a larger global role. These capacity limits exist in two domains: the diplomatic corps and the institutional architecture of the defense ministry. Relative to its size, India has a

\footnotetext{
${ }^{59}$ Dhruva Jaishankar, "The India-China Summit in Wuhan Was No Reset," Lowy Institute, Interpreter, May 10, 2018, https://www.lowyinstitute.org/the-interpreter/india-china-summitwuhan-was-no-reset.

60 Tarapore, "India's Slow Emergence as a Regional Security Actor,” 170.

${ }^{61}$ Aaron L. Friedberg, "Competing with China," Survival 60, no. 3 (2018): 7.
} 
very small foreign service that is quantitatively on par with that of New Zealand or Singapore. ${ }^{62}$ This limits the number of diplomatic functions that can be undertaken at any one time and requires the Ministry of External Affairs to constantly prioritize competing demands. As India's prominence on the world stage has grown, these demands have only increased over time as more countries seek to engage India on a broader range of issues. Individual diplomats must constantly pick and choose what tasks to focus on and their ability to take on additional responsibilities is limited. Consequently, foreign officials have been self-deterred from placing demands on their Indian counterparts out of a fear that it might be "overloading the Indian system." ${ }^{3}$ This problem not only limits India's functions in existing multilateral meetings but also constrains the government's ability to embrace new diplomatic initiatives and groupings. A similar capacity problem also exists in the Ministry of Defense as there is only one joint secretary (U.S. assistant secretary equivalent) in charge of international cooperation for the entire world. Moreover, the Indian defense ministry does not have a counterpart to U.S. offices that are devoted to political-military affairs and regional developments. As a result, the strategic dimensions of India's Act East policy, in

62 Daniel Markey, "Developing India's Foreign Policy ‘Software,” Asia Policy, no. 8 (July 2009): 73-96; and Shashi Tharoor, Pax Indica: India and the World of the 21st Century (New York: Penguin Books, 2012), 319, 336-37.

63 Tanvi Madan, "What in the World Is India Able to Do? India's State Capacity for Multilateralism," in Shaping the Emerging World: India and the Multilateral Order, ed. Waheguru Pal Singh Sidhu, Pratap Bhanu Mehta, and Bruce Jones (Washington, D.C.: Brookings Institution Press, 2013), 97. 
terms of military-to-military contacts, exercises, and exchange of views is limited. 64

Fourth, in the infrastructure space, India and the United States are not well placed to meet Asia's needs, meaning that Indo-U.S. cooperation on their connectivity strategy will neither be easy, nor assured. Like then secretary Hillary Clinton's "New Silk Road” before it, former secretary of state John Kerry's vision of an Indo-Pacific Economic Corridor linking South and Southeast Asia in a network of trade and physical ties garnered much attention at the time of its announcement, but there has been little follow-through. ${ }^{65}$ Unlike China, the U.S. government does not have the ability to direct American firms to undertake infrastructure mega-projects or make investments in other parts of the world. To its credit, the Trump administration has set aside funds for Indo-Pacific Economic Corridor, but the development and success of this initiative remains to be seen. ${ }^{66}$ For its part, the Indian government lacks capital and the capacity to implement a large-scale infrastructure development program abroad. ${ }^{67}$ Consequently, for both

${ }^{64}$ For more on problems in the defense ministry, see Anit Mukherjee and Manohar Thyagaraj, "Competing Exceptionalisms: U.S.-India Defense Relationship," Journal of Defense Studies 6, no. 2 (2012): 18.

65 John Kerry, "Remarks at the Center for American Progress' India: 2020 Program," Center for American Progress, Washington, D.C., July 28, 2014, https://2009-

2017.state.gov/secretary/remarks/2014/07/229870.htm.

66 Alyssa Ayres, "Pompeo's Indo-Pacific Strategy Is Just a Start," CNN, July 31, 2018, https://edition.cnn.com/2018/07/30/opinions/pompeos-indo-pacific-strategy-opinionayres/index.html.

${ }^{67}$ Prabir De, "India's Emerging Connectivity with Southeast Asia: Progress and Prospects," Asian Development Bank Institute, ADBI Working Paper Series, no. 507, December 2014, https://www.adb.org/sites/default/files/publication/156362/adbi-wp507.pdf. For more on connectivity between India and Myanmar, see V.S. Seshadri, Transforming Connectivity Corridors between India and Myanmar into Development Corridors (New Delhi: Research and Information System for Developing Countries, 2014), http://ris.org.in/images/RIS_images/pdf/Trans\%20Report.pdf. 
Washington and New Delhi, enhancing region connectivity will be a slow and challenging process.

Finally, the notion of a joint U.S.-India approach to Southeast Asia raises concerns among countries in the region. Unnerved by China's assertive behavior and island-building activities, in recent years Southeast Asian countries have generally welcomed a larger role for the United States, India and other extraregional powers, such as France, Japan and the EU68 Their diplomatic ambitions, however, have been mainly to embed all these powers in various multilateral, ASEAN-centric forums. They have welcomed engagement with extraregional powers but, importantly, on a bilateral, one-to-one basis. If Washington and New Delhi were to jointly approach any of these countries, they would likely face opposition out of a fear such actions were explicitly directed against China. It is not surprising, therefore, that the countries of Southeast Asia are not very keen on supporting the re-emergence of the Quad-the consultative grouping of the United States, India, Japan, and Australia-because they are concerned such an assembly will undermine ASEAN centrality. ${ }^{69}$

\section{What Can Be Done?}

If India and the United States wish to enhance their cooperation in Southeast Asia, what are the most favorable areas to focus on? As a preliminary step toward

\footnotetext{
68 For more about hedging and alignment behavior in Southeast Asia, see Shambaugh, "U.S. China Rivalry in Southeast Asia," 93-103.

69 Joel Ng, “The Quadrilateral Conundrum: Can ASEAN Be Persuaded?” RSIS, RSIS Commentary, no. 120, July 17, 2018.
} 
any meaningful coordination, Washington and New Delhi should set up a dedicated forum to exchange views and actively encourage cooperation in Southeast Asia. The two states currently have a maritime security dialogue but its composition suggests Southeast Asia is not a major area of focus. ${ }^{70}$

One promising area to focus on is strengthening the existing regional security architecture. In analyzing the U.S. pivot and India's Act East policy, Sourabh Gupta has concluded that the best arena for partnership is in "multilateral security constructs that are UN-flagged or come under broad-based umbrellas such as the ASEAN Regional Forum or ASEAN Defense Ministers Meeting Plus," the latter being a meeting of the ASEAN defense ministers and the organization's eight dialogue partners. ${ }^{71}$ India has traditionally felt comfortable working within regional security institutions and has embraced initiatives like the ADMM-Plus, the Regional Cooperation Agreement on Combating Piracy and Armed Robbery against Ships in Asia (ReCAAP), and the Information Fusion Centre, which focuses on regional maritime information-sharing. Fortunately, there are indications that the United States is also increasingly invested in regional multilateral forums. ${ }^{72}$ Therefore, despite the internal divisions plaguing ASEAN-it is important for Washington and New Delhi to give attention to ASEAN-led regional security initiatives, even if just for symbolic reasons.

\footnotetext{
${ }^{70}$ Ministry of External Affairs (India), "Third Round of the India-U.S. Maritime Security Dialogue," Press Release, May 2, 2018.

${ }^{71}$ Sourabh Gupta, “The U.S. Pivot and India's Look East," East Asia Forum, June 20, 2012, http://www.eastasiaforum.org/2012/06/20/the-us-pivot-and-india-s-look-east/.

72 Mary Fides Quintos and Joycee Teodoro, "Moving ASEAN-U.S. Security Relations to a New Level?" East-West Center, Asia Pacific Bulletin, no. 256, April 15, 2014, http://www.eastwestcenter.org/publications/moving-asean-us-security-relations-new-level.
} 
Maritime domain awareness (MDA) and maritime capacity-building in partner countries is another area for potential cooperation. Both countries are currently working on enhancing their shared MDA in the Indian Ocean region, yet from the standpoint of real-time situational awareness, many key parts of maritime Southeast Asia remain mare incognitum..$^{73}$ India and the United States can help build connections among the various national maritime surveillance agencies in the region to create a network that would enhance MDA from the Andaman Islands through to the east coast of the Philippines. The United States has already contributed some funds to build MDA capacity of Philippines and Indonesia and is exploring projects in Vietnam, Malaysia and Thailand. ${ }^{74}$ The ultimate aim would be to pool the surveillance capabilities of each state to develop a shared awareness of the real-time situation in the air and seas of Southeast Asia. There are certainly capacity shortfalls that inhibit MDA in the region, but lack of trust among neighbors is also an important obstacle. New Delhi and Washington can leverage their existing relationships to bridge some of these gaps. According to Admiral Sunil Lanba, India's chief of naval staff, this is an area of priority for the Indian Navy and has already operationalized agreements with a dozen Indian Ocean littoral nations to share white shipping information. ${ }^{75}$ The efficacy of U.S.India cooperation on MDA would, of course, be enhanced if India signed the Basic

\footnotetext{
${ }^{73}$ Abhijit Singh, "Searching for a High Note in U.S.-India Maritime Partnership," War on the Rocks, May 4, 2018, https://warontherocks.com/2018/05/searching-for-a-high-note-in-the-u-sindia-maritime-partnership/.

74 U.S. Department of State, "Fact Sheet: U.S. Building Maritime Capacity in Southeast Asia," https://id.usembassy.gov/our-relationship/policy-history/embassy-fact-sheets/fact-sheet-u-sbuilding-maritime-capacity-in-southeast-asia/.

75 Dinakar Peri, "Full Text of Interview with Admiral Sunil Lanba, Chief of Naval Staff," Hindu, November 4, 2017.
} 
Exchange and Cooperation Agreement for Geospatial Intelligence-the final outstanding "foundational agreement" that could underpin robust military-tomilitary cooperation between the United States and India. ${ }^{76}$ If such an accord were reached, the two partners would be able to exchange geospatial information for both civilian and military purposes that would facilitate ocean mapping and other maritime monitoring activities.

A parallel initiative to augmenting MDA would be a coordinated effort to enhance the capabilities of regional states to police their own exclusive economic zones. Japan is already working to build the capacity of the Philippine and Vietnamese coast guards via the transfer of surface vessels and joint training exercises, while Australia has provided the Philippine navy with similar assistance. ${ }^{77}$ The United States and India can contribute to these efforts by supplying communications and sensor systems that are interoperable with the Indian and U.S. Navies to enhance situational awareness. The Indian Navy can also be a source of expertise, particularly for countries in which joint training with the United States would controversial. Although many of these efforts are already underway individually, a coordinated approach would help ensure maximum returns to each nation's endeavor. Prior consultations about security assistance priorities in Southeast Asia could help de-conflict, and perhaps even coordinate, their efforts.

\footnotetext{
${ }^{76}$ Mark Rosen and Douglas Jackson, "The U.S.-India Defense Relationship: Putting the Foundational Agreements in Perspective," CNA Paper, February 2017, https://www.cna.org/CNA_files/PDF/DRM-2016-U-013926-Final2.pdf.

77 The United States has also transferred decommissioned Coast Guard cutters to the Philippines and Vietnam.
} 
Third, the U.S. and India should re-emphasize enhancing connectivity between South and Southeast Asia. The focus should be on implementing existing projects, however, rather than proposing increasingly grandiose region-wide economic corridors that are never translated into reality. A good starting point is the India-Myanmar-Thailand highway, which was first proposed in 2002. A lack of financial and institutional support in all three countries led the project to languish for years, however the Modi administration has recently declared that it will be operational by the end of $2019 .{ }^{78}$ Ensuring that this project hits its target will be key to establishing India's reputation as a credible partner. On its side, the United States can work with countries such as Japan or institutions such as the World Bank or the Asian Development Bank to help provide the necessary financing for planned extensions of the highway to Vietnam, Laos, and Cambodia. ${ }^{79}$ The United States can also provide funding and expertise for "smart logistics" along this trade corridor whereby integrated systems track cargo vehicles and transmit customs manifestos, rendering border crossings a seamless exercise.

Counterterrorism intelligence cooperation in Southeast Asia is a final area for potential cooperation between the two countries. As with India and the United States, all the countries of the region are concerned about ISIS gaining a foothold

\footnotetext{
78 “India-Myanmar-Thailand Trilateral Highway by 2019,” Mint, January 23, 2018.

${ }^{79}$ To overcome the problem of a lack of capital, there are some who envisage a growing role for Japan. The issue was discussed at the U.S.-India-Japan trilateral dialogue in 2018. See U.S. State Department, "Joint Statement on the U.S.-India-Japan Trilateral Meeting," April 5, 2018, https://www.state.gov/r/pa/prs/ps/2018/04/280254.htm. More recently, reports have surfaced about nascent discussions between India, the United States, Japan, and Australia on a joint regional infrastructure project that would be an alternative to China's Belt and Road Initiative. "Australia, U.S., India and Japan in Talks to Establish Belt and Road Alternative" Reuters, February 18, 2018.
} 
in Southeast Asia as well as the spread of extremist Salafist ideology in Malaysia, Philippines and Indonesia. In recent years, the two partners have intensified their bilateral counterterrorism cooperation via joint training and intelligence sharing. It could be productive to extend that conversation beyond South Asia to examine what both countries can do to prevent radicalization and entrenchment of militant groups in Southeast Asia. ${ }^{80}$ Such efforts could also be expanded to include active cooperation with various countries in the region.

\section{Conclusion: Working Together, But in Parallel}

The transformation in U.S.-Indian relations that has occurred in the past fifteen years has resulted in an apparent congruence of interests between the two nation's policies toward the Asia-Pacific broadly and Southeast Asia in particular. Taking their cues from increasingly common diplomatic positions on developments in the region, a number of analysts have suggested that Indo-U.S. cooperation in Southeast Asia is a likely proposition. ${ }^{81}$ The underlying assumption is that a convergence of interests could lead the two countries into a gradual, if unspoken, "alliance."

Expectations of close Indo-U.S. cooperation in Southeast Asia overlook both the limits to their partnership and the constraints on India's ability to play a

\footnotetext{
${ }^{80}$ For more on India's counterterrorism cooperation with South East Asian countries see Julio S. Amador, "ASEAN-India Cooperation in Counterterrorism," in Karen Stoll Farrell and Sumit Ganguly (ed.), Heading East: Security, Trade, and Environment between India and Southeast Asia (New Delhi: Oxford University Press, 2016).

${ }^{81}$ Karl Inderfurth and Ted Osius, "India's 'Look East' and America's 'Asia Pivot': Converging Interests," CSIS, U.S.-India Insight 3, no. 3, March 2013, http://csis.org/publication/indiaslook-east-and-americas-asia-pivot-converging-interests.
} 
significant role east of the Strait of Malacca. ${ }^{82}$ For these reasons, extensive diplomatic consultation and shared assessments of regional security issues have not yet led to active cooperation on a policy level. Despite these constraints, however, there are still some steps that India and the United States can take to better coordinate their policies toward Southeast Asia. Regular diplomatic consultations are crucial to this effort and should be prioritized. In addition, both countries are working in parallel to build up the militaries of partner states in the region. To an extent, their efforts are complementary, as India is able to provide training, logistical, and other value-added skills to countries that operate Russian military platforms and also can provide low-tech military systems and subsystems. Finally, the two countries should work with like-minded ASEAN countries to support regional security initiatives and strengthen the twin concepts of ASEAN unity and centrality.

Despite being economically interdependent with China, most Southeast Asian states want other major powers to remain engaged in the region to hedge against political domination by Beijing. ${ }^{83}$ The presence of multiple rising powers, competing territorial claims, and nationalism means that the region is likely to witness a protracted great-power competition for influence. ${ }^{84}$ Undoubtedly this will exacerbate tensions in the U.S.-China and India-China relationships. How

\footnotetext{
${ }^{82}$ Rahul Roy-Chaudhury and Kate Sullivan de Estrada, "India, the Indo-Pacific and the Quad," Survival 60, no. 3 (2018): 181-94.

${ }^{83}$ Deepa M. Ollapally, “How Does India's Look East Policy Look after 25 Years?” Asia Policy 13, no. 2 (2018), 146.

${ }^{84}$ C. Raja Mohan, “China's Rise, America's Pivot, and India's Asian Ambiguity," Seminar, no. 641, January 2013, http://www.india-seminar.com/2013/641/641_c_raja_mohan.htm.
} 
these three powers interact with each other will have major consequences for the Southeast Asia. For the moment, it appears that U.S. and Indian policies toward the region will move in parallel—working independently in pursuit of a common goal. It remains to be seen if in response to growing Chinese assertiveness their partnership can rise to another level. 